\title{
Age, segment, and horn disease affect expression of cytokines, growth factors, and receptors in the epidermis and dermis of the bovine claw
}

\author{
J. A. Mills, ${ }^{*}$ D. S. Zarlenga, $†$ P. L. Habecker, $\ddagger$ and R. M. Dyer $\S^{1}$ \\ *Department of Pathology and Cell Biology, Thomas Jefferson University Hospital, Philadelphia, PA 19107 \\ †Animal Parasitic Diseases Laboratory, ANRI, US Department of Agriculture, Beltsville, MD 20705 \\ łDepartment of Pathobiology, University of Pennsylvania School of Veterinary Medicine, George D. Widner Hospital for Large Animals, \\ New Bolton Center, Kennett Square 19348 \\ §Department of Animal and Food Sciences, College of Agriculture and Natural Resources, University of Delaware, Newark 19717
}

\begin{abstract}
The aim of this study was to examine changes in RNA expression for growth factors, cytokines, and receptors in epidermal-dermal tissues of the bovine claw relative to host age, claw segment, and disease state of the horn. Epidermal-dermal tissues were collected from the coronary, wall, sole, and bulb segments of 8- to 9-mo-old Holstein fetuses, normal adult cows, and adult cows with sole ulceration. Anatomic and pathologic characteristics were determined in tissues stained with eosin and hematoxylin, and RNA expression levels were evaluated using real-time, quantitative PCR. In normal tissues, certain RNA expression levels were clearly affected by host age: 290.0-, 610.0-, 53.4-, and 8.1-fold greater expression of granulocyte-macrophage colony stimulating factor was observed in fetal coronary, wall, sole, and bulb segment relative to adult tissues, respectively. A claw segment effect was also observed in that IL- $1 \alpha$ expression was greater (1.59-fold) in the normal adult wall relative to the coronary segment, and IL18 expression was greater (16.2-fold) in the normal adult sole compared with the coronary segment and 2.88 greater in the fetal sole relative to the bulb segment. Sole ulceration was associated with hemorrhage, thrombosis, inflammation, and striking increases in IL-1 $\beta$, IL-18, and inducible nitric oxide synthase, and with less dramatic, albeit measurable, changes in IL-1 type I receptor, IL-1 receptor antagonist, and tumor necrosis factor- $\alpha$. Amidst striking increases in keratinocyte growth factor receptor (i.e., 21.0-fold, 10.4-fold, 0, and 21.6-fold in the coronary, wall, sole, and bulb segments, respectively), a concomitant decrease occurred in keratinocyte growth factor (i.e., 0.80-, 0.54-, 0.56-, and 0.72 -fold, respectively). The results demonstrated changes in disease state and, to a lesser extent, claw segment and were accompanied by alterations in the
\end{abstract}

Received February 2, 2009.

Accepted September 11, 2009.

${ }^{1}$ Corresponding author: rdyer@udel.edu
RNA expression of several cytokines, growth factors, and receptors present in the normal claw.

Key words: cytokine, growth factor, sole ulceration

\section{INTRODUCTION}

Steady-state tissue homeostasis in the integument is maintained by populations of self-renewing progenitor cells in the basal cell layer. Daughter cells remain as progenitor cells or follow programs of post-mitotic, terminal differentiation in the suprabasal epidermal layers (Clayton et al., 2007). In the cutaneous microenvironment, IL- $1 \alpha$ and IL-1 $\beta$ have been shown to increase growth factor expression that drives and regulates keratinocyte proliferation and differentiation in the epidermal cell layers. Perturbations in the expression of cutaneous cytokines; for example, IL-1, IL-6, transforming growth factor (TGF)- $\alpha$, and tumor necrosis factor- $\alpha$ (TNF- $\alpha$ ) (Chedid et al., 1994) can result in changes in the expression of keratinocyte growth factor (KGF), granulocyte-macrophage colony stimulating factor (GMCSF), and other cytokines, leading to disturbances in keratinocyte proliferation, keratinization, and cornification. In disease states, these homeostatic disturbances alter integument health. Inasmuch as the dermis and epidermis of the bovine claw are derivatives of the integument, horn growth approximating $5 \mathrm{~mm} /$ mo must arise from a balanced program of keratinocyte proliferation, differentiation, and apoptosis in the basal and suprabasal layers of the claw epidermis. Accordingly, one might expect epidermal and dermal structures of the bovine claw to express a variety of the same mediators regulating epidermal homeostasis in human and murine integuments (Smola et al., 1993).

Even though there are many pathological descriptions of claw disorders (Collick et al., 1997), the cell and molecular mechanisms of pathogenesis are not understood. Little is known about epidermal-dermal interactions, the mediator roles in these interactions, or the effect of disease on keratinocyte homeostasis in the claw. Dynamic changes in the expression of one or more 
of the mediators of keratinocyte homeostasis could trigger inflammation, increase metalloproteinase activity (Hendry et al., 2003), alter keratinocyte proliferation and differentiation, and result in poor quality claw horn production (Budras et al., 1996). The purpose of this investigation was to address 4 questions related to the expression of targeted cytokines, growth factors, and receptors: (1) Does horn epidermis-dermis of the bovine claw express collections of immune-related molecules known to orchestrate tissue homeostasis in the integument? (2) Are expression levels congruent among the different segments of the claw? (3) Are expression levels within and between different segments of the claw affected by host age and therefore age of the claw; and (4) Does the disease state of the claw horn affect expression levels within and between different segments of the claw?

\section{MATERIALS AND METHODS}

\section{Epidermal and Dermal Tissues of the Bovine Claw}

Epidermal-dermal samples of coronary, wall, sole, and bulb segments were obtained from the normal lateral hind claws of Holstein fetuses 8 to 9 mo in gestation (n $=6$ ) and the normal lateral hind claws of freshly killed, lactating Holstein cows $(\mathrm{n}=6)$. Each tissue sample contained 3.5 to $4.0 \mathrm{~cm}^{2}$ of epidermis and dermis from the abaxial coronary, the abaxial wall, the sole, and bulb segment of the lateral claw (Figure 1, panels A to D). Samples were also collected from the abaxial coronary, abaxial wall, the sole, and bulb segments of the left lateral hind claw with ulceration in region 4 of the sole segment (Shearer et al., 2004). Claws were selected with gross ulcerative lesions appearing as discrete, circumscribed losses of horn tissue restricted to the sole segment. Epidermis of the sole segment was visible in each ulcerated area of sole horn. No other lesions were present on the claw. All tissues were flash frozen in liquid nitrogen, and stored at $-80^{\circ} \mathrm{C}$ until processed. Tissues of the coronary, wall, sole, and bulb segment were also placed in $10 \%$ formalin and paraffin embedded. The paraffin-embedded specimens were cut into $4-\mu \mathrm{m}$ sections and placed on silane-coated glass slides. Hematoxylin and eosin-stained sections were evaluated at $40 \times$ to $600 \times$ magnification for anatomic-pathologic abnormalities.

\section{RNA Isolation and cDNA Synthesis}

Total RNA was extracted in duplicate from each tissue using the RNeasy Mini Kit and on-column DNase treatment according to the manufacturer's protocol (Qiagen Sciences, Germantown, MD). Briefly, $20 \mathrm{mg}$ of frozen tissue in RLT lysis buffer (Qiagen) was homogenized with a rotor-stator homogenizer, mixed with $70 \%$ ethanol, and centrifuged $(8,000 \times g, 15 \mathrm{~s})$ through an RNA binding column. On-column DNase digestion was performed and the column washed twice to remove DNA digests and contaminating proteins. Column-adherent RNA was subsequently eluted with double-distilled water. Total RNA concentrations were determined by spectroscopy $\left(\mathrm{A}_{257}\right)$ and sample integrity was assessed on $1.5 \%$ denaturing agarose gels. Complementary DNA synthesis was performed on duplicate extracts using the Transcriptor cDNA Synthesis Kit (Roche Diagnostics Corp., Indianapolis, IN) according to the manufacturer's recommendations with $1 \mu \mathrm{g}$ of RNA in $20-\mu \mathrm{L}$ reaction mixture.

\section{Endogenous Gene Standards}

To normalize samples, a candidate housekeeping gene was required. Cyclophilin-A (Cyclo), GAPDH, hypoxanthine (HPRT), $\beta$-glucuronidase ( $\beta$-Gluc), ribosomal protein L15 (RPL15), phosphoglycerokinase (PGK), $\beta$-actin, and ubiquitin-C (Ubiq) were evaluated in tissues from the coronary, wall, sole, and bulb segments of fetal $(\mathrm{n}=2)$, adult cow $(\mathrm{n}=2)$, and ulcerated adult cow $(\mathrm{n}=2)$ claws. Expression of each potential endogenous, internal standard was compared with RNA 18S internal standard by subtraction of the internal standard cycle threshold $\left(\mathbf{C}_{\mathbf{T}}\right)$ from the RNA $18 \mathrm{~S}$ internal standard cycle threshold.

\section{Quantitative Real-Time PCR Analysis}

Real-time PCR was performed in an Abi Prism 7900 (Applied Biosystems, Foster City, CA) in 384-well optical plates. All immune-related molecules examined in this study are listed in Table 1. Real-time PCR was performed in triplicate for each cDNA preparation and Ubiq served as the internal control. Complementary DNA was diluted 1:4 and transcripts were determined using $1 \mu \mathrm{L}$ (25 ng/sample) of diluted cDNA, $10 \mu \mathrm{L}$ of SYBR Green QPCR master mix (Applied Biosystems), and $1 \mu \mathrm{L}(1 \mu M)$ gene-specific primers (Table 1$)$. Amplification efficiency required generating a titration curve of DNA accumulation from several samples to obtain a standard curve in which efficiency $(\mathrm{E})=-1$ $+10^{(-1 / \text { slope })}$ (data not shown). The PCR reactions were performed as follows: 10 -min denaturation at $95^{\circ} \mathrm{C}$ followed by 40 cycles of $15 \mathrm{~s}$ at $95^{\circ} \mathrm{C}$ and $1 \mathrm{~min}$ at $60^{\circ} \mathrm{C}$. The PCR products were visualized on $1.5 \%$ agarose gel (data not shown) to verify the presence of a single product with the predicted amplicon length (ranging from 80 to $150 \mathrm{bp}$ depending on the gene). Amplicons were sequenced (data not shown) and melting curves 
A.

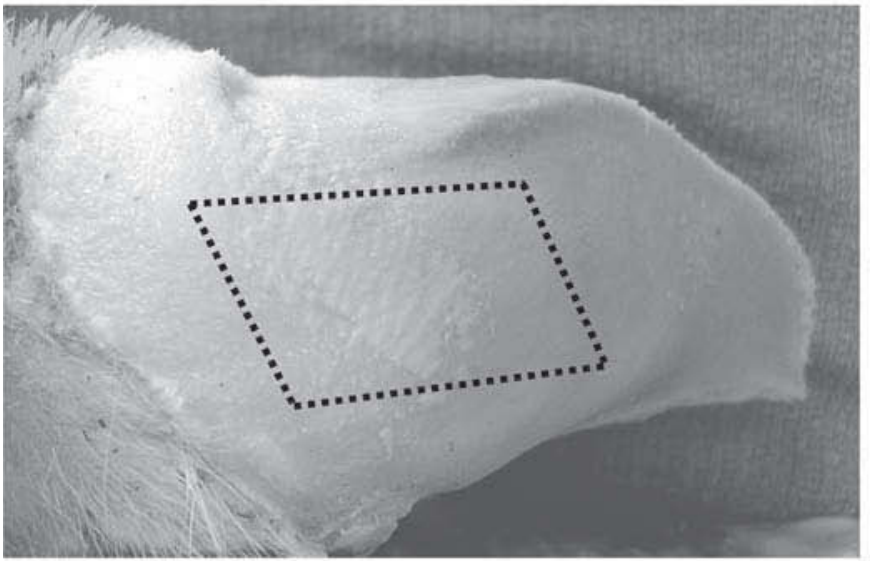

B.

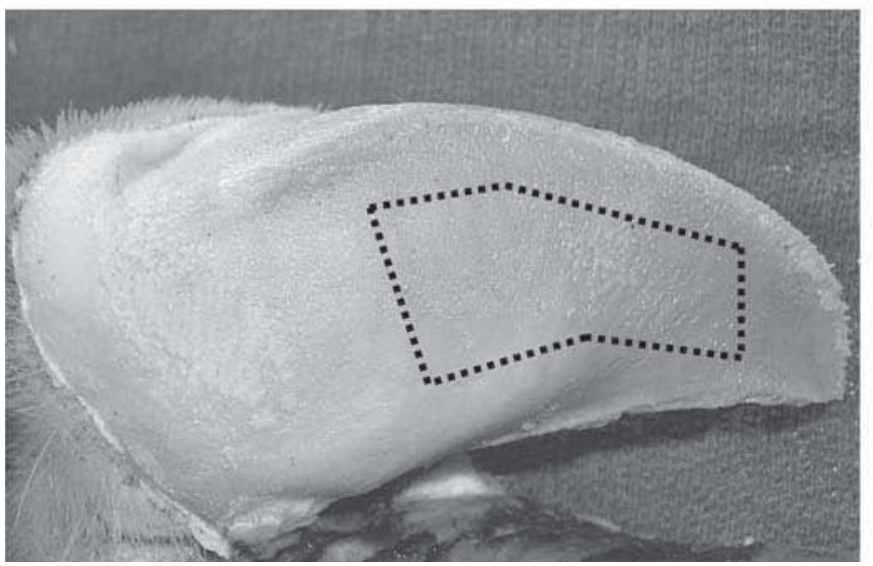

C.

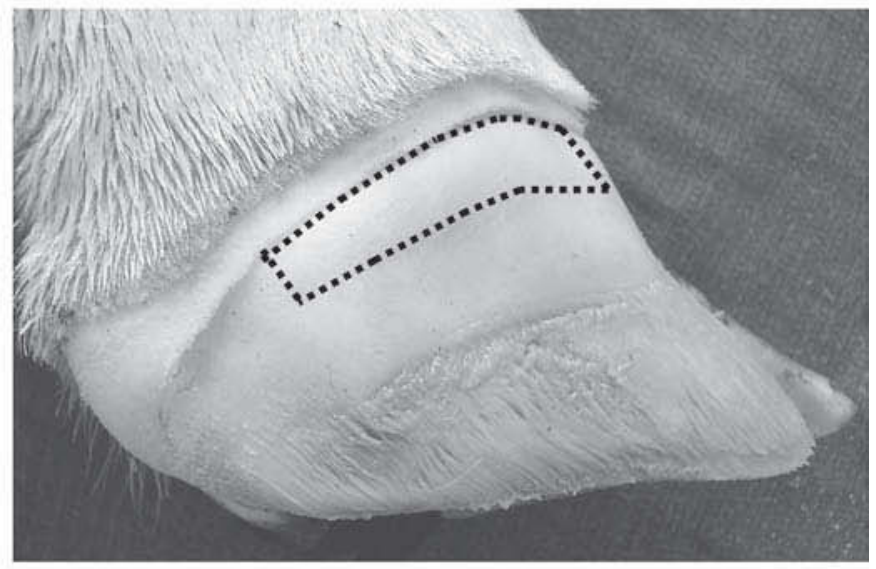

D.

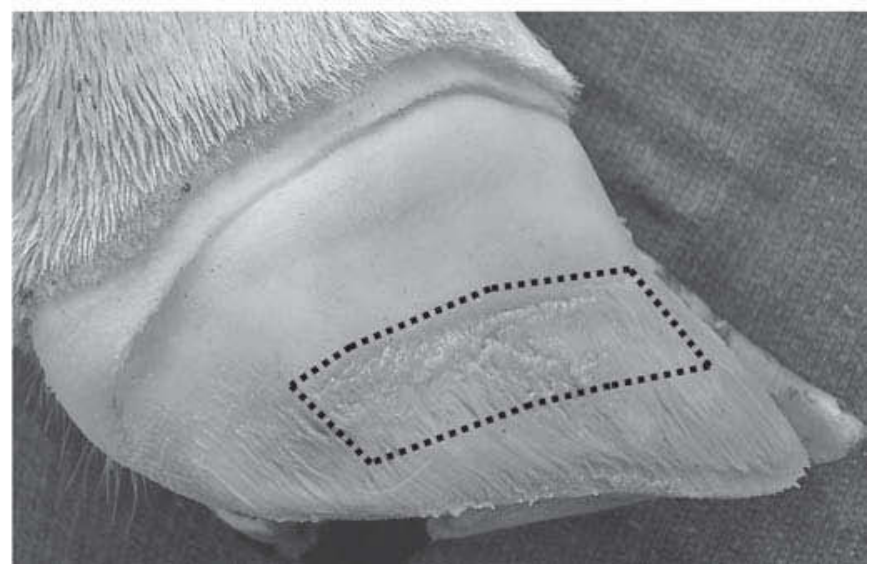

Figure 1. Approximate location of samples from the epidermal-dermal tissues of the claw after removal of the claw horn capsule. Sample of (A) bulb segment, (B) sole segment, (C) coronary segment, and (D) wall segment.

performed to verify presence of a single product with the predicted melting temperature (data not shown).

\section{Statistical Analysis}

Data were normalized to Ubiq as an internal reference, and relative expression (RE) of target genes was presented in arbitrary units (AU) as

$$
\mathrm{RE}=2^{-\left[\left(\mathrm{CTsample}_{\mathrm{n}}-\mathrm{CTUbiq}_{\mathrm{n}}\right)-\left(\mathrm{CTsample}_{\text {avg }}-\mathrm{CTUbiq}_{\text {avg })}\right)\right]}
$$

(Livak and Schmittgen, 2001). Statistical analysis was performed using the mixed procedure (2001 version; SAS Institute, Cary, NC) utilizing the probability of the difference (pdiff) for comparison of means. Significance was defined as $P \leq 0.05$ and a trend was defined as $0.05<P \leq 0.10$.

\section{RESULTS}

\section{Identification of Ubiq as an Endogenous Reference in the Bovine Claw}

Real-time reverse transcriptase-PCR analysis revealed large changes in $\beta$-Gluc, RPL15, and $\beta$-actin (data not shown) expression across claw tissues. Small changes in transcript expression were observed with Cyclo, GAPDH, HPRT, and PGK rendering them suitable candidates for internal references. Expression of Ubiq was virtually invariant across age and claw segment (Table $2 ; P<0.05$ ).

\section{Pathology of Sole Ulceration}

Histological evaluation of tissues from normal fetal (Figure 2A) and normal adult claws (Figure 2B) were 
Table 1. Primers used for real-time PCR amplification and primer efficiency per gene

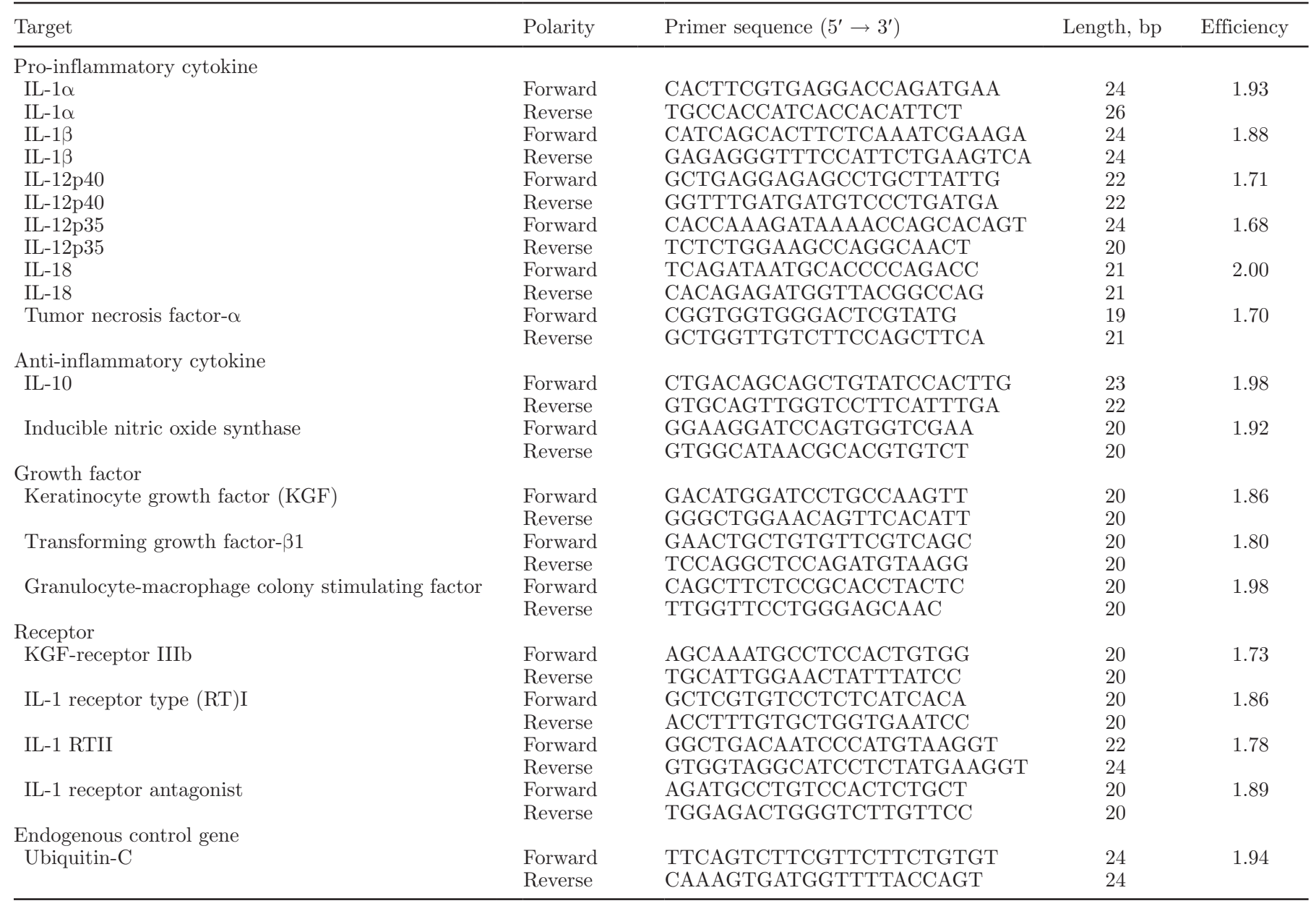

as described by Collick et al. (1997) and Thoefner et al. (2005) and lacked any evidence of pathology. In contrast, widespread inflammation and tissue destruction was observed in tissues of claws with sole ulceration (Figure $2 \mathrm{C}$ and 2D). The dermis of the sole contained eosinophilic, thick collagen fibers separated by areas of edema and extravascular red blood cells (Figure 2C). Mononuclear, lymphocytic, and polymorphonuclear infiltrates were distributed throughout the dermis, particularly in the papilla with elevation in cellularity throughout the length of the papilla in some instances. Some papillae were distended with edema, leukocyte infiltrates, and extravascular erythrocytes in association with dermal vessels that were engorged with erythrocytes, monocytes, and polymorphonuclear cells. Many capillaries were lined by enlarged endothelial cells. Leukocyte infiltrates also appeared in the wall of muscular arterioles. Inflammatory cell numbers increased in the dermis

Table 2. Expression (mean \pm SEM) of internal standards within fetal, normal adult, and ulcerated adult lateral hind claws source

\begin{tabular}{lccrrr}
\hline & \multicolumn{5}{c}{ Gene $^{2}$} \\
\cline { 2 - 6 } Tissue source $^{1}$ & Cyclo & GAPDH & HPRT & \multicolumn{1}{c}{ PGK } & \multicolumn{1}{c}{ Ubiq } \\
\hline Fetal & $9.6 \pm 0.3^{\mathrm{a}}$ & $8.7 \pm 0.4^{\mathrm{a}}$ & $13.4 \pm 0.5^{\mathrm{a}}$ & $11.2 \pm 0.4^{\mathrm{a}}$ & $10.6 \pm 0.4^{\mathrm{a}}$ \\
Normal adult & $9.0 \pm 0.4^{\mathrm{ab}}$ & $7.9 \pm 0.3^{\mathrm{b}}$ & $12.0 \pm 0.4^{\mathrm{b}}$ & $9.8 \pm 0.5^{\mathrm{b}}$ & $10.0 \pm 0.3^{\mathrm{a}}$ \\
Ulcerated adult $^{\mathrm{b}}$ & $8.4 \pm 0.3^{\mathrm{b}}$ & $7.8 \pm 0.2^{\mathrm{b}}$ & $11.8 \pm 0.4^{\mathrm{b}}$ & $10.1 \pm 0.3^{\mathrm{b}}$ & $9.9 \pm 0.5^{\mathrm{a}}$ \\
\hline
\end{tabular}

${ }^{\mathrm{a}, \mathrm{b}}$ Means with different superscripts indicate differences across tissue type $(P<0.05)$.

${ }^{1}$ Each tissue type consisted of tissue samples from the bulb, coronary, sole, and wall segments $(\mathrm{n}=4)$.

${ }^{2} \mathrm{Cyclo}=$ cyclophilin-A; HPRT $=$ hypoxanthine; PGK $=$ phosphoglycerokinase Ubiq = ubiquitin-C. 
of the sole immediately below the stratum basale. Cell debris was evident in many areas of the dermis. The basal cell layer of the epidermis contained mononuclear and polymorphonuclear cells between and above the epidermal cells. In some areas, basal cell structure was indistinct and associated with cellular vacuolation and the presence of small, pyknotic, dark-staining nuclei. Several areas of epidermis were thickened, edematous, and dyskeratotic, and contained hemorrhage (Figure 2D). Although most extensive in the sole segment, these changes were also evident across the coronary, wall, and bulb segments of every ulcerated claw.

\section{Variation in Gene Expression Relative to Claw Segment}

Expression of cytokines, growth factors and receptors was affected by segment for all claws (Tables 3, 4 , and $5 ; P<0.05)$. In the normal adult claw, the amount of IL-1 $\alpha$ (Table 3) was greater in the wall than the coronary segment of the claw $(P<0.05)$. In the normal fetal claw, the amount of IL-18 transcripts in the bulb was greater than in the sole of the claw (Table 4; $P<0.05$ ). Surprisingly, ulcerated claws showed no segmental differences in expression for all transcripts except the p40 subunit of IL-12 (IL-12p40), which was greater in the sole than the wall (Table $4 ; P<0.05$ ).

\section{Variation in Gene Expression Relative to the Disease State of the Claw}

Sole ulceration affected expression of a variety of cytokines and growth factor receptors across all segments of ulcerated claws compared with normal adult claws (Tables 6, 7, and 8; $P<0.05$ ). Within every segment of the ulcerated claw, the amounts of IL-1 $1 \beta$, inducible nitric oxide synthase (iNOS), and KGF receptor (KGFR) transcripts were markedly increased above amounts in normal adult claws (Tables 6 and 8; $P<0.05)$. Interleukin-1 type I receptor (IL-1RTI), p35 subunit of IL-12 (IL-12p35), IL-12p40, IL-18, and TNF- $\alpha$ were modestly elevated within 2 or 3 segments (Table 6 and $7 ; P<0.05$ ) and trended toward increased expression in all the other segments of ulcerated claws. There was a substantial decrease in the amounts of KGF transcripts within every segment of the ulcerated claw (Table 8; $P<0.05$ ).

Cytokine, growth factor, and growth factor receptor expression was also elevated in ulcerated claws compared with fetal claws. Expression of IL-1 $\beta$, IL-1 receptor agonist (IL-1RA), IL-10, IL-12p35, and KGFR (Tables 6,7 , and $8, P<0.05$ ) was elevated within each of the 4 segments of the diseased claw. Interleukin-1RTI, IL-10, TNF- $\alpha$, and iNOS (Tables 6,7 , and $8 ; P<0.05$ ) were elevated within 3 of the 4 segments of the diseased claw, and IL-1 $\alpha$, IL-1RTII, and IL-12p40 (Tables 6 and 7; $P<0.05)$ were elevated in 1 or 2 of the 4 segments. Expression of KGF decreased in all segments of ulcerated claws (Table $8 ; P<0.05$ ). The amount of TGF- $\beta$ and GMCSF in ulcerated claws was less than in fetal claws (Table 8) because of high levels of expression in fetal claw compared with any adult claw. Note, regardless of the direction of change in transcript amounts, the changes consistently occurred at least in the sole in which the ulcerative lesion was located (Tables 6, 7, and $8 ; P<0.05)$.

\section{Variation in Gene Expression Relative to Host Age}

Expression of IL-1 $\alpha$, IL-1 type II receptor (IL1RTII), IL-1RA (Table 6), IL-10, IL-12p40, IL-18, TNF- $\alpha$ (Table 7), TGF- $\beta$, and GMCSF (Table 8) varied within one or more segments across age $(P<0.05)$. Within segments, amounts of IL-1RTII (Table 6), IL-18 (Table 7), TGF- $\beta$, and GMCSF transcripts (Table 8) were greater or tended to be greater in fetal compared with adult claws $(P<0.05)$. In contrast, amounts of IL-1 $\alpha$, IL-1RA (Table 6), IL-10, IL-12p40, and TNF- $\alpha$ transcripts (Table 7) were greater or tended to be greater in adult compared with fetal claws (Table 6 and 7; $P<0.05)$. Expression of IL-1 $\beta$, IL-RTI, IL-12p35, iNOS, KGF, and KGFR were similar in fetal and adult claws $(P>0.05)$.

\section{DISCUSSION}

Results of the investigation established that dermal and epidermal tissues of the claw were awash in proand anti-inflammatory cytokines, growth factors, and receptors known to regulate epidermal homeostasis in the integument. Moreover, the data indicated that the claw was enveloped in a reservoir of IL-1. Both fibroblast and keratinocytes may be the sources of IL- $1 \alpha / \beta$, the receptors and the receptor antagonist in the bovine claw (Groves et al., 1996; Kondo and Jimbow, 1998; Kessler-Becker et al., 2004). Moreover, the presence of IL-1RI, IL-1RTII, and IL-1RA implied that activities of IL- $1 \alpha$ and IL-1 $\beta$ are closely regulated in normal claws. Interleukin-1RI mediates IL- $1 \alpha$ and IL-1 $\beta$ activities, whereas the IL-1 decoy receptor (IL-1RTII) and antagonist (IL-1RA) block IL- $1 \alpha$ and IL-1 $\beta$ activities in the integument (Groves et al., 1996; Rauschmayr et al., 1997).

Ubiquitous expression of IL-1, GMCSF, and KGF transcripts in the claw supports the possibility that IL- $1 \alpha$ and IL-1 $\beta$ regulate KGF and GMCSF expression during normal epidermal homeostasis. Smola et al. (1993) showed that both GMCSF and KGF (FGF- 
A.

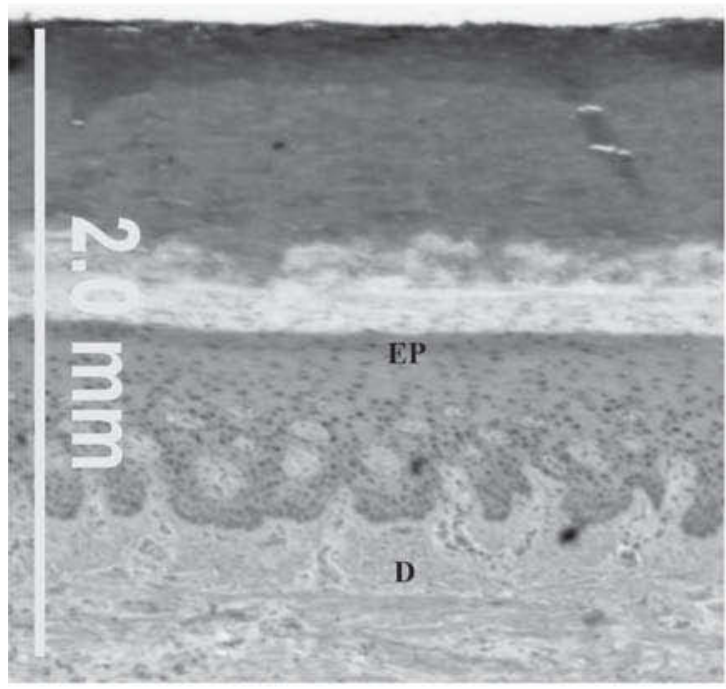

B.

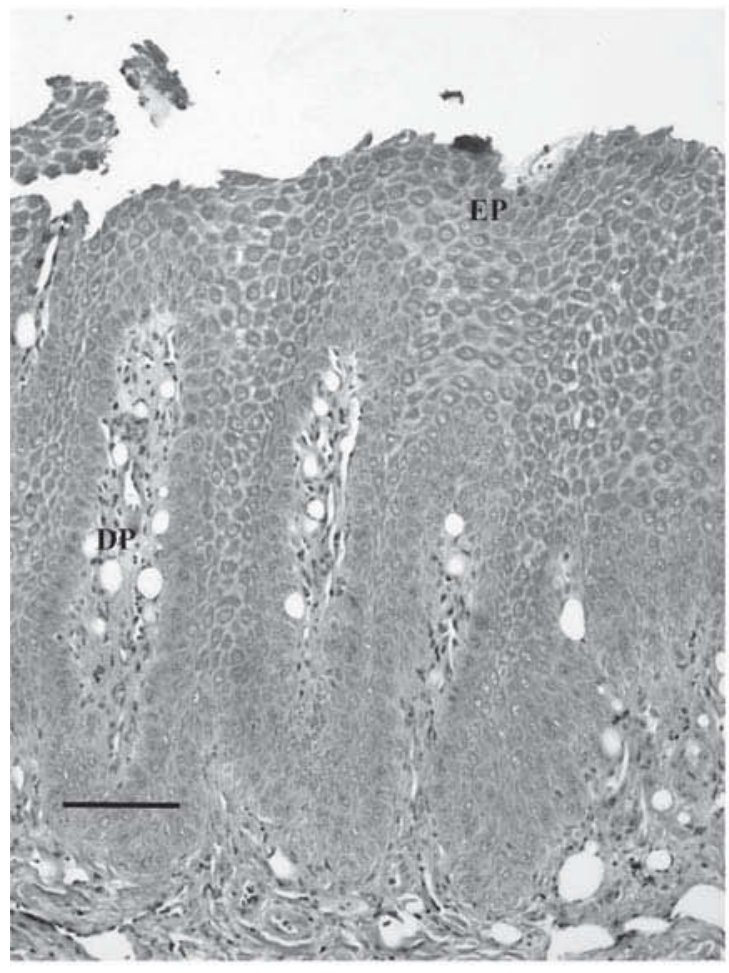

C.

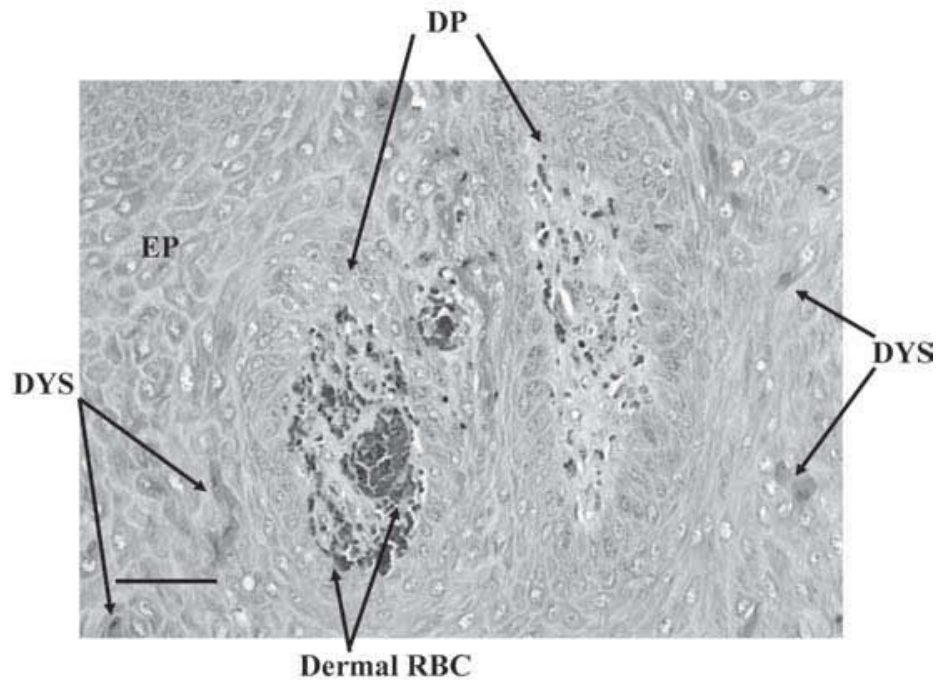

D.

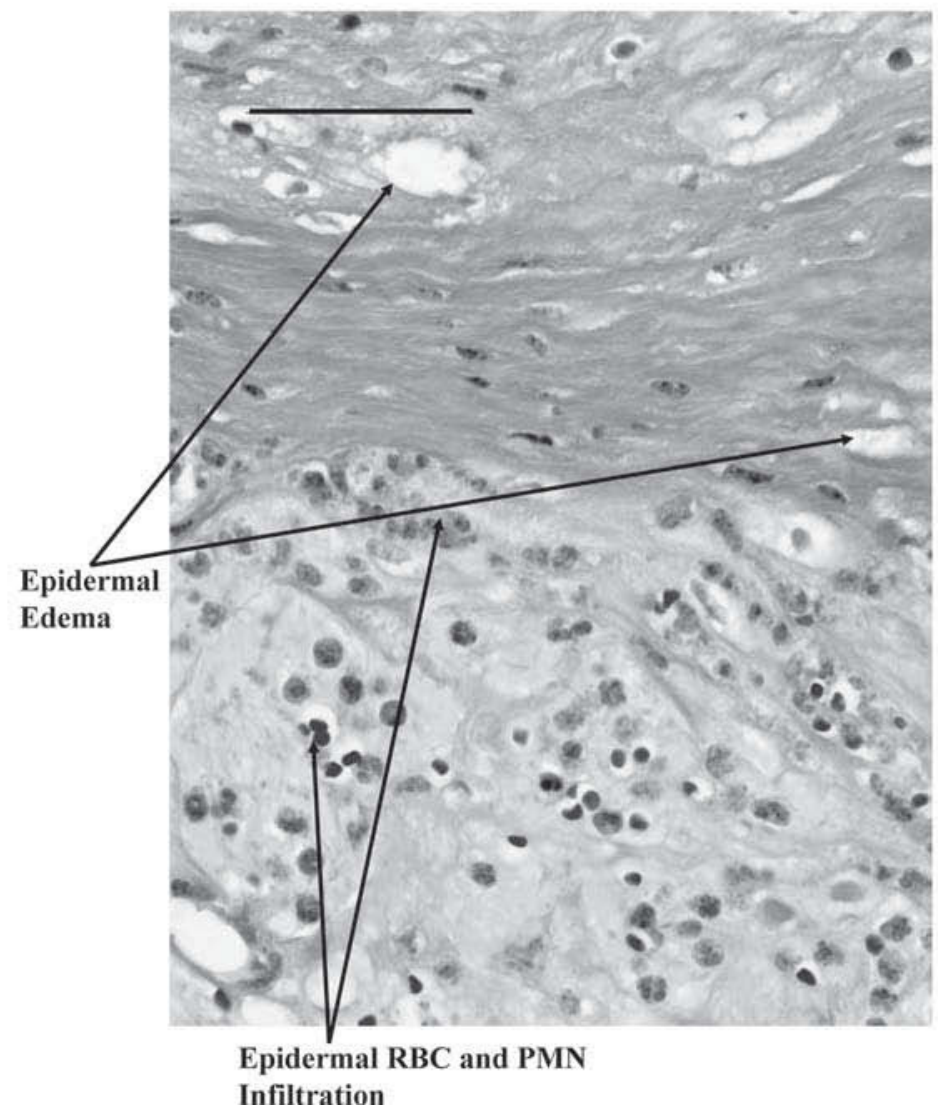

Figure 2. Representative sections of the epidermis and dermis of the bovine claw. (A) Normal fetal (bar $=2.0 \mathrm{~mm})$ and (B) normal adult sole $($ bar $=100 \mu \mathrm{m})$. (C) ulcerated adult claw showing dermal hemorrhage and epidermal dyskeratosis $($ bar $=50 \mu \mathrm{m})$; $(\mathrm{D})$ ulcerated sole showing widespread dyskeratosis, epidermal edema, hemorrhage and neutrophil infiltration (bar $=100 \mu \mathrm{m})$ (hematoxylin and eosin). RBC $=$ hemorrhage, $\mathrm{EP}=$ epidermis, $\mathrm{D}=$ dermis, $\mathrm{DP}=$ dermal papilla, $\mathrm{DYS}=$ dyskeratotic keratinocyte, $\mathrm{PMN}=$ neutrophil. 
Table 3. Expression (mean \pm SEM; $n=6$ ) of IL-1 family mRNA in the epidermis and dermis across anatomic segments of the bovine lateral hind claw for fetal, adult, and ulcerated tissue ${ }^{1}$

\begin{tabular}{|c|c|c|c|c|c|}
\hline Claw segment & $\mathrm{IL}-1 \alpha$ & IL-1 $\beta$ & IL-1RTI & IL-1RTII & IL-1RA \\
\hline \multicolumn{6}{|l|}{ Fetal } \\
\hline Bulb & $1.02 \pm 0.47^{\mathrm{a}}$ & $1.50 \pm 0.52^{\mathrm{a}}$ & $1.37 \pm 1.30^{\mathrm{a}}$ & $23.7 \pm 8.44^{\mathrm{a}}$ & $0.09 \pm 0.09^{\mathrm{a}}$ \\
\hline Coronary & $0.69 \pm 0.66^{\mathrm{a}}$ & $1.18 \pm 0.73^{\mathrm{a}}$ & $3.34 \pm 3.39^{\mathrm{a}}$ & $13.5 \pm 6.73^{\mathrm{a}}$ & $0.04 \pm 0.07^{\mathrm{a}}$ \\
\hline Sole & $1.07 \pm 0.22^{\mathrm{a}}$ & $1.31 \pm 0.85^{\mathrm{a}}$ & $2.10 \pm 2.60^{\mathrm{a}}$ & $20.9 \pm 5.59^{\mathrm{a}}$ & $0.04 \pm 0.12^{\mathrm{a}}$ \\
\hline Wall & $0.59 \pm 0.48^{\mathrm{a}}$ & $1.75 \pm 0.65^{\mathrm{a}}$ & $2.42 \pm 2.33^{\mathrm{a}}$ & $17.3 \pm 5.16^{\mathrm{a}}$ & $0.04 \pm 0.11^{\mathrm{a}}$ \\
\hline \multicolumn{6}{|l|}{ Adult } \\
\hline Bulb & $1.83 \pm 0.47^{\mathrm{ab}}$ & $1.90 \pm 1.03^{\mathrm{a}}$ & $2.05 \pm 2.61^{\mathrm{a}}$ & $9.2 \pm 5.31^{\mathrm{a}}$ & $0.17 \pm 0.14^{\mathrm{a}}$ \\
\hline Coronary & $1.57 \pm 0.60^{\mathrm{b}}$ & $1.31 \pm 0.86^{\mathrm{a}}$ & $2.23 \pm 2.86^{\mathrm{a}}$ & $12.3 \pm 5.97^{\mathrm{a}}$ & $0.16 \pm 0.11^{\mathrm{a}}$ \\
\hline Sole & $1.68 \pm 0.39^{\mathrm{ab}}$ & $1.83 \pm 0.76^{\mathrm{a}}$ & $2.30 \pm 2.96^{\mathrm{a}}$ & $3.7 \pm 10.31^{\mathrm{a}}$ & $0.06 \pm 0.07^{\mathrm{a}}$ \\
\hline Wall & $2.49 \pm 0.39^{\mathrm{a}}$ & $1.57 \pm 0.82^{\mathrm{a}}$ & $1.78 \pm 2.51^{\mathrm{a}}$ & $9.8 \pm 4.93^{\mathrm{a}}$ & $0.20 \pm 0.14^{\mathrm{a}}$ \\
\hline \multicolumn{6}{|l|}{ Ulcerated } \\
\hline Bulb & $1.06 \pm 0.47^{\mathrm{a}}$ & $9.02 \pm 6.18^{\mathrm{a}}$ & $3.52 \pm 3.22^{\mathrm{a}}$ & $15.6 \pm 8.78^{\mathrm{a}}$ & $0.10 \pm 0.12^{\mathrm{a}}$ \\
\hline Coronary & $0.97 \pm 0.68^{\mathrm{a}}$ & $9.43 \pm 6.23^{\mathrm{a}}$ & $5.18 \pm 3.27^{\mathrm{a}}$ & $3.70 \pm 3.66^{\mathrm{a}}$ & $0.11 \pm 0.10^{\mathrm{a}}$ \\
\hline Sole & $0.64 \pm 0.59^{\mathrm{a}}$ & $9.89 \pm 6.43^{\mathrm{a}}$ & $2.66 \pm 2.86^{\mathrm{a}}$ & $14.30 \pm 8.06^{\mathrm{a}}$ & $0.26 \pm 0.17^{\mathrm{a}}$ \\
\hline Wall & $1.67 \pm 0.99^{\mathrm{a}}$ & $9.72 \pm 6.48^{\mathrm{a}}$ & $2.28 \pm 1.76^{\mathrm{a}}$ & $9.70 \pm 5.79^{\mathrm{a}}$ & $0.18 \pm 0.09^{\mathrm{a}}$ \\
\hline
\end{tabular}

${ }^{\mathrm{a}, \mathrm{b}}$ Within a cytokine, means with different superscripts indicate differences across segments $(P<0.05)$.

${ }^{1} \mathrm{IL}-1 \mathrm{RTI}=\mathrm{IL}-1$ type I receptor; IL-1RTII = IL-1 type II decoy receptor; IL-1RA = IL-1 receptor antagonist.

7) were of dermal cell origin and mediate growth and differentiation of keratinocyte progenitor cells in basal epithelial layers. Keratinocytes expressed IL-1 $\alpha$ and IL-1 $\beta$ in response to fibroblast-derived KGF and GMCSF stimulation, and IL- $1 \alpha$ and IL-1 $\beta$ stimulated expression of KGF and GMCSF in dermal fibroblasts. Thus, data from the bovine claw are consistent with a similar paracrine loop regulating homeostasis of claw horn keratinocytes (Smola et al., 1993; Maas-Szabowski et al., 2000).

Fetal horn tissue differentiates in an ideal environment of balanced nutrient availability, sterility and the absence of gastrointestinal microbial activity, strain, force, and other environmental effects on the claw. Surprisingly, the distribution of cytokines, growth factors, and receptors in these claws differed very little from normal adult claws. The extraordinarily high expression of GMCSF in fetal epidermal-dermal tissues was surprising. Inasmuch as GMCSF induced keratinocyte hyper-proliferation (Groves et al., 1996), this growth factor may drive keratinocyte proliferation in lategestation claws. Amounts of TGF- $\beta 1$ transcripts were low across all segments of normal and ulcerated adult claws yet relatively high in fetal claws. The significance of TGF- $\beta 1$ transcripts in the claw is unclear as this cytokine orchestrates extracellular matrix and collagen remodeling and keratinocyte migration, converts keratinocytes to a basal cell phenotype, and diminishes keratinocyte pro-inflammatory cytokine production (Jiang et al., 1995; Zavadil et al., 2001; Amendt et al., 2002; Ishida et al., 2006). Elevated expression of TGF- $\beta 1$ in fetal claw tissues may reflect the need for these ac-

Table 4. Expression (mean $\pm \mathrm{SEM} ; \mathrm{n}=6$ ) of cytokine mRNA in the epidermis and dermis across anatomic segments of the bovine lateral hind claw for fetal, adult, and ulcerated tissue ${ }^{1}$

\begin{tabular}{|c|c|c|c|c|c|}
\hline Claw segment & IL-10 & IL-12p35 & IL-12p40 & IL-18 & TNF- $\alpha$ \\
\hline \multicolumn{6}{|l|}{ Fetal } \\
\hline Bulb & $0.88 \pm 0.57^{\mathrm{a}}$ & $5.60 \pm 8.90^{\mathrm{a}}$ & $1.03 \pm 0.58^{\mathrm{a}}$ & $9.84 \pm 3.07^{\mathrm{a}}$ & $0.49 \pm 0.46^{\mathrm{a}}$ \\
\hline Coronary & $1.55 \pm 0.98^{\mathrm{a}}$ & $11.70 \pm 10.40^{\mathrm{a}}$ & $0.89 \pm 0.42^{\mathrm{a}}$ & $4.56 \pm 2.58^{\mathrm{ab}}$ & $1.74 \pm 0.97^{\mathrm{a}}$ \\
\hline Sole & $1.80 \pm 1.73^{\mathrm{a}}$ & $5.60 \pm 8.9^{\mathrm{a}}$ & $1.56 \pm 0.87^{\mathrm{a}}$ & $3.42 \pm 1.96^{\mathrm{b}}$ & $1.62 \pm 0.63^{\mathrm{a}}$ \\
\hline Wall & $1.72 \pm 1.24^{\mathrm{a}}$ & $20.70 \pm 9.5^{\mathrm{a}}$ & $3.30 \pm 1.72^{\mathrm{a}}$ & $5.03 \pm 2.79^{\mathrm{ab}}$ & $1.35 \pm 0.47^{\mathrm{a}}$ \\
\hline \multicolumn{6}{|l|}{ Adult } \\
\hline Bulb & $6.85 \pm 4.42^{\mathrm{a}}$ & $16.10 \pm 9.9^{\mathrm{a}}$ & $4.31 \pm 3.79^{\mathrm{a}}$ & $0.80 \pm 0.73^{\mathrm{a}}$ & $1.92 \pm 1.16^{\mathrm{a}}$ \\
\hline Coronary & $2.69 \pm 2.10^{\mathrm{a}}$ & $31.50 \pm 10.30^{\mathrm{a}}$ & $3.10 \pm 2.87^{\mathrm{a}}$ & $0.11 \pm 0.10^{\mathrm{a}}$ & $1.82 \pm 0.84^{\mathrm{a}}$ \\
\hline Sole & $4.00 \pm 3.46^{\mathrm{a}}$ & $13.70 \pm 12.30^{\mathrm{a}}$ & $2.30 \pm 1.99^{\mathrm{a}}$ & $1.78 \pm 1.66^{\mathrm{a}}$ & $2.91 \pm 1.19^{\mathrm{a}}$ \\
\hline Wall & $6.60 \pm 2.93^{\mathrm{a}}$ & $22.5 \pm 9.3^{\mathrm{a}}$ & $2.89 \pm 2.79^{\mathrm{a}}$ & $0.78 \pm 0.67^{\mathrm{a}}$ & $1.19 \pm 0.69^{\mathrm{a}}$ \\
\hline \multicolumn{6}{|l|}{ Ulcerated } \\
\hline Bulb & $9.65 \pm 2.69^{\mathrm{a}}$ & $22.30 \pm 8.20^{\mathrm{a}}$ & $4.46 \pm 2.89^{\mathrm{ab}}$ & $5.60 \pm 2.22^{\mathrm{a}}$ & $3.75 \pm 2.81^{\mathrm{a}}$ \\
\hline Coronary & $6.00 \pm 2.36^{\mathrm{a}}$ & $13.00 \pm 8.90^{\mathrm{a}}$ & $1.84 \pm 2.85^{\mathrm{ab}}$ & $5.70 \pm 2.33^{\mathrm{a}}$ & $6.68 \pm 2.31^{\mathrm{a}}$ \\
\hline Sole & $8.29 \pm 2.59^{\mathrm{a}}$ & $26.00 \pm 11.30^{\mathrm{a}}$ & $5.47 \pm 2.05^{\mathrm{a}}$ & $5.32 \pm 3.18^{\mathrm{a}}$ & $3.03 \pm 2.32^{\mathrm{a}}$ \\
\hline Wall & $6.60 \pm 2.85^{\mathrm{a}}$ & $15.05 \pm 9.40^{\mathrm{a}}$ & $1.03 \pm 1.82^{\mathrm{b}}$ & $5.94 \pm 2.60^{\mathrm{a}}$ & $3.36 \pm 2.22^{\mathrm{a}}$ \\
\hline
\end{tabular}

${ }^{\mathrm{a}, \mathrm{b}}$ Within a cytokine, means with different superscripts indicate differences across segments $(P<0.05)$.

${ }^{1} \mathrm{IL}-12 \mathrm{p} 35=\mathrm{IL}-12$ p35 chain; IL-12p40 = IL-12 p40 chain; TNF- $\alpha=$ tumor necrosis factor $\alpha$. 
Table 5. Expression (mean \pm SEM; $n=6$ ) of cytokine, growth factor, and receptor $\mathrm{mRNA}$ in the epidermis and dermis across anatomic segments of the bovine lateral hind claw for fetal, adult, and ulcerated tissue ${ }^{1}$

\begin{tabular}{|c|c|c|c|c|c|}
\hline Claw segment & TGF- $\beta$ & iNOS & GMCSF & KGF & KGFR \\
\hline \multicolumn{6}{|l|}{ Fetal } \\
\hline Bulb & $0.64 \pm 0.24^{\mathrm{a}}$ & $0.49 \pm 0.45^{\mathrm{a}}$ & $51.70 \pm 14.0^{\mathrm{a}}$ & $14.40 \pm 4.2^{\mathrm{a}}$ & $6.60 \pm 5.30^{\mathrm{a}}$ \\
\hline Coronary & $0.25 \pm 0.20^{\mathrm{a}}$ & $1.23 \pm 1.10^{\mathrm{a}}$ & $68.90 \pm 5.9^{\mathrm{a}}$ & $12.30 \pm 3.9^{\mathrm{a}}$ & $3.70 \pm 4.60^{\mathrm{a}}$ \\
\hline Sole & $0.40 \pm 0.29^{\mathrm{a}}$ & $2.69 \pm 2.12^{\mathrm{a}}$ & $51.10 \pm 14.2^{\mathrm{a}}$ & $17.50 \pm 5.8^{\mathrm{a}}$ & $8.50 \pm 5.20^{\mathrm{a}}$ \\
\hline Wall & $0.48 \pm 0.20^{\mathrm{a}}$ & $1.50 \pm 1.24^{\mathrm{a}}$ & $61.00 \pm 7.6^{\mathrm{a}}$ & $16.10 \pm 4.4^{\mathrm{a}}$ & $10.40 \pm 9.80^{\mathrm{a}}$ \\
\hline \multicolumn{6}{|l|}{ Adult } \\
\hline Bulb & $0.03 \pm 0.02^{\mathrm{a}}$ & $1.09 \pm 0.67^{\mathrm{a}}$ & $0.38 \pm 0.21^{\mathrm{a}}$ & $15.30 \pm 6.7^{\mathrm{a}}$ & $1.11 \pm 0.75^{\mathrm{a}}$ \\
\hline Coronary & $0.02 \pm 0.02^{\mathrm{a}}$ & $1.12 \pm 1.13^{\mathrm{a}}$ & $0.22 \pm 0.32^{\mathrm{a}}$ & $16.00 \pm 7.6^{\mathrm{a}}$ & $1.05 \pm 0.82^{\mathrm{a}}$ \\
\hline Sole & $0.02 \pm 0.02^{\mathrm{a}}$ & $2.07 \pm 1.54^{\mathrm{a}}$ & $0.47 \pm 0.23^{\mathrm{a}}$ & $6.30 \pm 6.1^{\mathrm{a}}$ & $1.30 \pm 1.13^{\mathrm{a}}$ \\
\hline Wall & $0.04 \pm 0.02^{\mathrm{a}}$ & $1.12 \pm 0.82^{\mathrm{a}}$ & $0.23 \pm 0.15^{\mathrm{a}}$ & $5.70 \pm 5.8^{\mathrm{a}}$ & $1.32 \pm 1.25^{\mathrm{a}}$ \\
\hline \multicolumn{6}{|l|}{ Ulcerated } \\
\hline Bulb & $0.04 \pm 0.02^{\mathrm{a}}$ & $12.50 \pm 2.1^{\mathrm{a}}$ & $3.41 \pm 3.10^{\mathrm{a}}$ & $4.30 \pm 4.4^{\mathrm{a}}$ & $33.40 \pm 6.60^{\mathrm{a}}$ \\
\hline Coronary & $0.04 \pm 0.02^{\mathrm{a}}$ & $7.80 \pm 3.6^{\mathrm{a}}$ & $4.43 \pm 4.16^{\mathrm{a}}$ & $3.30 \pm 3.0^{\mathrm{a}}$ & $33.10 \pm 5.70^{\mathrm{a}}$ \\
\hline Sole & $0.05 \pm 0.03^{\mathrm{a}}$ & $12.30 \pm 2.1^{\mathrm{a}}$ & $4.59 \pm 2.79^{\mathrm{a}}$ & $6.60 \pm 5.8^{\mathrm{a}}$ & $23.10 \pm 6.50^{\mathrm{a}}$ \\
\hline Wall & $0.03 \pm 0.02^{\mathrm{a}}$ & $8.00 \pm 3.7^{\mathrm{a}}$ & $5.89 \pm 3.34^{\mathrm{a}}$ & $4.90 \pm 4.3^{\mathrm{a}}$ & $26.10 \pm 8.80^{\mathrm{a}}$ \\
\hline
\end{tabular}

${ }^{a}$ Within a cytokine, means with different superscripts indicate differences across segments $(P<0.05)$.

${ }^{1} \mathrm{TGF}-\beta=$ transforming growth factor $\beta$; iNOS = inducible nitric oxide synthase; GMCSF = granulocytemacrophage colony stimulating factor; KGF $=$ keratinocyte growth factor; KGFR $=$ KGF receptor.

tivities during morphogenesis of fetal horn. Like IL-1, transcriptional expression of TGF- $\beta$ may inaccurately reflect functional TGF- $\beta$ activity because latent forms of the protein must be activated by proteolytic cleavage. The caveat with TGF- $\beta 1$ transcriptional data is that it does not account for biologic activity inasmuch as latent forms of TGF- $\beta 1$ must be activated by proteolytic cleavage.

A relatively small number of cytokines (IL-1 $\alpha$, IL-18, and IL-12p40) showed different amounts of expression relative to tissue location in normal adult, fetal, and ulcerated claws, respectively. The reasons for these findings remain unclear but mechanical strain has been shown to augment keratinocyte and fibroblast expression of IL-1 (Takei et al., 1998). Greater amounts of IL-1 in the sole and wall correspond to the strain distribution described by Hinterhofer et al. (2005) and may reflect tissue responses to mechanical forces during weight bearing.

Several events were associated with sole ulceration in this investigation. The morphologic and mediator changes in the ulcerated claws indicated the lesions were in the inflammatory stages of wound healing. Surprisingly, inflammation occurred in the coronary, wall and bulb segment of ulcerated claws even though the gross ulcerative lesion was restricted to region 4 of the sole (Shearer et al., 2004). These findings provided pathologic-anatomic evidence that severe phase 3 sole

Table 6. Expression (mean $\pm \mathrm{SEM} ; \mathrm{n}=6$ ) of IL-1 family mRNA within the epidermis and dermis of fetal, adult, and ulcerated claws

\begin{tabular}{|c|c|c|c|c|c|}
\hline Tissue source & IL-1 $\alpha$ & IL-1 $\beta$ & IL-1RTI & IL-1RTII & IL-1RA \\
\hline \multicolumn{6}{|l|}{ Bulb } \\
\hline Fetal & $1.02 \pm 0.46^{\mathrm{a}}$ & $0.16 \pm 0.05^{\mathrm{b}}$ & $1.30 \pm 0.62^{\mathrm{b}}$ & $2.30 \pm 0.52^{\mathrm{a}}$ & $0.09 \pm 0.05^{\mathrm{b}}$ \\
\hline Adult & $1.03 \pm 0.35^{\mathrm{a}}$ & $0.19 \pm 0.41^{\mathrm{b}}$ & $2.05 \pm 0.41^{\mathrm{b}}$ & $0.93 \pm 0.49^{b}$ & $0.17 \pm 0.08^{\mathrm{ab}}$ \\
\hline Ulcerated & $1.06 \pm 0.43^{\mathrm{a}}$ & $5.10 \pm 3.40^{\mathrm{a}}$ & $3.50 \pm 0.77^{\mathrm{a}}$ & $1.56 \pm 0.21^{\mathrm{b}}$ & $0.19 \pm 0.03^{\mathrm{a}}$ \\
\hline \multicolumn{6}{|l|}{ Coronary } \\
\hline Fetal & $0.67 \pm 0.44^{\mathrm{b}}$ & $0.18 \pm 0.08^{\mathrm{b}}$ & $2.10 \pm 0.21^{\mathrm{b}}$ & $1.35 \pm 0.64^{\mathrm{a}}$ & $0.03 \pm 0.08^{\mathrm{b}}$ \\
\hline Adult & $1.57 \pm 0.37^{\mathrm{ab}}$ & $0.31 \pm 0.15^{\mathrm{b}}$ & $2.23 \pm 0.25^{\mathrm{ab}}$ & $1.23 \pm 0.40^{\mathrm{a}}$ & $0.16 \pm 0.07^{\mathrm{ah}}$ \\
\hline Ulcerated & $1.97 \pm 0.50^{\mathrm{ab}}$ & $4.30 \pm 1.08^{\mathrm{a}}$ & $2.66 \pm 0.20^{\mathrm{a}}$ & $0.91 \pm 0.31^{\mathrm{a}}$ & $0.21 \pm 0.06^{\mathrm{a}}$ \\
\hline \multicolumn{6}{|l|}{ Sole } \\
\hline Fetal & $0.82 \pm 0.15^{\mathrm{b}}$ & $0.14 \pm 0.07^{\mathrm{b}}$ & $2.31 \pm 0.61^{\mathrm{b}}$ & $1.89 \pm 0.27^{\mathrm{a}}$ & $0.05 \pm 0.07^{\mathrm{b}}$ \\
\hline Adult & $1.37 \pm 0.31^{\mathrm{a}}$ & $0.17 \pm 0.09^{\mathrm{b}}$ & $2.09 \pm 0.69^{\mathrm{b}}$ & $0.85 \pm 0.17^{\mathrm{b}}$ & $0.15 \pm 0.05^{\mathrm{ab}}$ \\
\hline Ulcerated & $1.09 \pm 0.22^{\mathrm{a}}$ & $2.40 \pm 1.42^{\mathrm{a}}$ & $5.67 \pm 2.61^{\mathrm{a}}$ & $1.07 \pm 0.22^{\mathrm{b}}$ & $0.24 \pm 0.06^{\mathrm{a}}$ \\
\hline \multicolumn{6}{|l|}{ Wall } \\
\hline Fetal & $0.49 \pm 0.38^{\mathrm{b}}$ & $0.18 \pm 0.08^{\mathrm{b}}$ & $1.42 \pm 0.74^{\mathrm{a}}$ & $2.00 \pm 0.53^{\mathrm{a}}$ & $0.04 \pm 0.03^{\mathrm{b}}$ \\
\hline Adult & $2.40 \pm 0.49^{\mathrm{a}}$ & $0.57 \pm 0.35^{\mathrm{b}}$ & $1.28 \pm 0.54^{\mathrm{a}}$ & $0.98 \pm 0.50^{\mathrm{b}}$ & $0.20 \pm 0.08^{\mathrm{a}}$ \\
\hline Ulcerated & $1.67 \pm 0.51^{\mathrm{ab}}$ & $4.70 \pm 1.62^{\mathrm{a}}$ & $2.54 \pm 1.46^{\mathrm{a}}$ & $1.40 \pm 0.38^{\mathrm{ab}}$ & $0.28 \pm 0.04^{\mathrm{a}}$ \\
\hline
\end{tabular}

${ }^{\mathrm{a}, \mathrm{b}}$ Within a cytokine, means with different superscripts indicate differences across tissue source $(P<0.05)$.

${ }^{1} \mathrm{IL}-1 \mathrm{RTI}=\mathrm{IL}-1$ type I receptor; IL-1RTII = IL-1 type II decoy receptor; IL-1RA = IL-1 receptor antagonist. 
Table 7. Expression (mean $\pm \mathrm{SEM} ; \mathrm{n}=6$ ) of cytokine $\mathrm{mRNA}$ within the epidermis and dermis of fetal, adult, and ulcerated claws ${ }^{1}$

\begin{tabular}{lccccc}
\hline Tissue source & IL-10 & IL-12p35 & IL-12p40 & IL-18 & TNF- $\alpha$ \\
\hline Bulb & & & & & \\
Fetal & $5.60 \pm 1.80^{\mathrm{b}}$ & $1.80 \pm 0.90^{\mathrm{b}}$ & $1.00 \pm 0.80^{\mathrm{b}}$ & $9.80 \pm 0.50^{\mathrm{a}}$ & $0.50 \pm 0.25^{\mathrm{c}}$ \\
Adult & $16.10 \pm 6.20^{\mathrm{a}}$ & $2.60 \pm 0.80^{\mathrm{ab}}$ & $5.30 \pm 2.80^{\mathrm{a}}$ & $0.80 \pm 0.20^{\mathrm{b}}$ & $1.92 \pm 0.22^{\mathrm{b}}$ \\
$\quad$ Ulcerated & $22.30 \pm 10.00^{\mathrm{a}}$ & $5.30 \pm 2.50^{\mathrm{a}}$ & $2.40 \pm 2.00^{\mathrm{ab}}$ & $5.60 \pm 1.60^{\mathrm{a}}$ & $2.75 \pm 0.32^{\mathrm{a}}$ \\
Coronary & & & & \\
$\quad$ Fetal & $11.70 \pm 5.20^{\mathrm{b}}$ & $2.00 \pm 0.90^{\mathrm{b}}$ & $0.90 \pm 0.50^{\mathrm{a}}$ & $4.50 \pm 1.50^{\mathrm{a}}$ & $1.70 \pm 0.33^{\mathrm{a}}$ \\
Adult & $23.50 \pm 7.80^{\mathrm{ab}}$ & $2.10 \pm 0.70^{\mathrm{b}}$ & $1.30 \pm 1.00^{\mathrm{a}}$ & $0.10 \pm 0.10^{\mathrm{b}}$ & $1.82 \pm 0.29^{\mathrm{a}}$ \\
Ulcerated & $31.50 \pm 12.00^{\mathrm{a}}$ & $4.80 \pm 0.80^{\mathrm{a}}$ & $0.80 \pm 0.60^{\mathrm{a}}$ & $5.30 \pm 3.60^{\mathrm{a}}$ & $2.00 \pm 0.42^{\mathrm{a}}$ \\
Sole & & & & \\
Fetal & $10.90 \pm 2.90^{\mathrm{b}}$ & $1.50 \pm 0.80^{\mathrm{b}}$ & $1.70 \pm 0.80^{\mathrm{b}}$ & $5.70 \pm 1.60^{\mathrm{a}}$ & $1.30 \pm 0.69^{\mathrm{b}}$ \\
Adult & $18.50 \pm 4.50^{\mathrm{a}}$ & $3.50 \pm 1.80^{\mathrm{ab}}$ & $7.30 \pm 1.70^{\mathrm{a}}$ & $0.90 \pm 0.60^{\mathrm{b}}$ & $1.96 \pm 0.75^{\mathrm{b}}$ \\
Ulcerated & $19.20 \pm 5.20^{\mathrm{a}}$ & $6.40 \pm 2.40^{\mathrm{a}}$ & $3.90 \pm 1.30^{\mathrm{b}}$ & $4.40 \pm 1.70^{\mathrm{a}}$ & $4.21 \pm 1.05^{\mathrm{a}}$ \\
Wall & & & & \\
Fetal & $15.50 \pm 6.30^{\mathrm{a}}$ & $2.10 \pm 1.60^{\mathrm{b}}$ & $2.30 \pm 1.50^{\mathrm{ab}}$ & $5.00 \pm 4.40^{\mathrm{ab}}$ & $1.35 \pm 0.35^{\mathrm{a}}$ \\
Adult & $22.50 \pm 8.50^{\mathrm{a}}$ & $3.10 \pm 0.80^{\mathrm{b}}$ & $3.80 \pm 1.10^{\mathrm{a}}$ & $0.80 \pm 0.30^{\mathrm{b}}$ & $1.20 \pm 0.54^{\mathrm{a}}$ \\
Ulcerated & $20.00 \pm 6.20^{\mathrm{a}}$ & $5.80 \pm 1.80^{\mathrm{a}}$ & $1.80 \pm 0.70^{\mathrm{b}}$ & $5.90 \pm 3.10^{\mathrm{ab}}$ & $2.36 \pm 0.37^{\mathrm{b}}$ \\
\hline
\end{tabular}

${ }^{\mathrm{a}-\mathrm{c}}$ Within a cytokine, means with different superscripts indicate differences across tissue source $(P<0.05)$.

${ }^{1} \mathrm{IL}-12 \mathrm{p} 35=\mathrm{IL}-12$ p35 chain; IL-12p40 = IL-12 p40 chain; TNF- $\alpha=$ tumor necrosis factor $\alpha$.

ulceration was a disorder of the entire claw unlike that described by Lischer et al. (2002) in uncomplicated sole ulcerations. Ulceration was associated with increased mRNA expression of the pro-inflammatory cytokines IL-1 $\beta$ ，IL-1RTI，IL-12p35，IL-12p40，IL-18，TNF- $\alpha$, and iNOS in the segment of the ulcerative lesion and across most if not all segments of the claw. Clearly, changes in mediator expression can affect the entire claw. Mediators normally expressed in healthy claw tissues were elevated in ulcerated horn disease in accord with the process proposed by Freedberg et al. (2001) in which injury "activated" keratinocytes via release of IL- $1 \alpha$ and IL-1 $\beta$. Activated keratinocytes secondarily increased expression of the pro-inflammatory cytokines and growth factors (Smola et al., 1993; Groves et al., 1996; Maas-Szabowski et al., 2000) described in these claws. Irritants, endotoxin, and pro-inflammatory cytokines elevated growth factor receptor and additional inflammatory cytokine expression in keratinocytes (Rauschmayr et al., 1997; Stoll et al., 1997; Freedberg et al., 2001; Banno et al., 2004). These cytokines are likely the cause of elevated iNOS mRNA in the claw and could explain the epidermal changes described by Hendry et al. (2003) in ulcerative claw lesions. Others showed that wound-related expression of IL-1 $\beta$, IL-1RI, IL-1RII, IL-6, chemokines, and chemokine receptors was also associated with leukocyte infiltrates of tissues (Cooper et al., 2005). Leukocytic infiltrates and dermal

Table 8. Expression (mean $\pm \mathrm{SEM} ; \mathrm{n}=6$ ) of cytokine mRNA within the epidermis and dermis of fetal, adult, and ulcerated claws ${ }^{1}$

\begin{tabular}{|c|c|c|c|c|c|}
\hline Tissue source & TGF- $\beta$ & iNOS & GMCSF & KGF & KGFR \\
\hline \multicolumn{6}{|l|}{ Bulb } \\
\hline Fetal & $1.60 \pm 0.70^{\mathrm{a}}$ & $0.50 \pm 0.40^{\mathrm{b}}$ & $51.80 \pm 26.8^{\mathrm{a}}$ & $14.30 \pm 4.60^{\mathrm{a}}$ & $1.00 \pm 0.60^{\mathrm{b}}$ \\
\hline Adult & $0.02 \pm 0.02^{\mathrm{b}}$ & $1.00 \pm 0.89^{\mathrm{b}}$ & $6.40 \pm 3.20^{\mathrm{b}}$ & $15.10 \pm 5.60^{\mathrm{a}}$ & $1.10 \pm 0.30^{\mathrm{b}}$ \\
\hline Ulcerated & $0.40 \pm 0.36^{\mathrm{b}}$ & $12.50 \pm 5.31^{\mathrm{a}}$ & $2.40 \pm 1.50^{\mathrm{b}}$ & $4.20 \pm 3.30^{\mathrm{b}}$ & $23.80 \pm 14.90^{\circ}$ \\
\hline \multicolumn{6}{|l|}{ Coronary } \\
\hline Fetal & $1.50 \pm 0.45^{\mathrm{a}}$ & $1.23 \pm 0.31^{\mathrm{b}}$ & $58.0 \pm 31.50^{\mathrm{a}}$ & $12.10 \pm 4.70^{\mathrm{a}}$ & $0.60 \pm 0.50^{\mathrm{b}}$ \\
\hline Adult & $0.02 \pm 0.01^{\mathrm{b}}$ & $1.12 \pm 0.28^{b}$ & $0.30 \pm 0.20^{\mathrm{b}}$ & $16.20 \pm 6.20^{\mathrm{a}}$ & $1.10 \pm 0.40^{\mathrm{b}}$ \\
\hline Ulcerated & $0.30 \pm 0.25^{\mathrm{b}}$ & $7.70 \pm 4.32^{\mathrm{a}}$ & $4.40 \pm 3.60^{\mathrm{b}}$ & $3.20 \pm 2.80^{\mathrm{b}}$ & $23.10 \pm 9.90^{\mathrm{a}}$ \\
\hline \multicolumn{6}{|l|}{ Sole } \\
\hline Fetal & $0.44 \pm 0.28^{\mathrm{a}}$ & $1.48 \pm 0.26^{\mathrm{b}}$ & $58.20 \pm 16.1^{\mathrm{a}}$ & $15.00 \pm 3.90^{\mathrm{a}}$ & $3.10 \pm 1.10^{\mathrm{a}}$ \\
\hline Adult & $0.03 \pm 0.02^{\mathrm{c}}$ & $1.60 \pm 0.40^{\mathrm{b}}$ & $1.09 \pm 0.80^{\mathrm{b}}$ & $10.90 \pm 1.80^{\mathrm{a}}$ & $1.60 \pm 0.50^{\mathrm{a}}$ \\
\hline Ulcerated & $0.15 \pm 0.13^{\mathrm{bc}}$ & $7.42 \pm 3.62^{\mathrm{a}}$ & $1.70 \pm 1.40^{\mathrm{b}}$ & $4.80 \pm 1.20^{\mathrm{b}}$ & $16.60 \pm 4.70^{\mathrm{b}}$ \\
\hline \multicolumn{6}{|l|}{ Wall } \\
\hline Fetal & $0.47 \pm 0.36^{\mathrm{a}}$ & $1.50 \pm 1.34^{\mathrm{ab}}$ & $61.0 \pm 27.2^{\mathrm{a}}$ & $16.20 \pm 3.40^{\mathrm{a}}$ & $0.80 \pm 0.70^{\mathrm{a}}$ \\
\hline Adult & $0.03 \pm 0.02^{\mathrm{b}}$ & $1.10 \pm 0.69^{\mathrm{b}}$ & $0.10 \pm 0.80^{\mathrm{b}}$ & $10.60 \pm 2.70^{\mathrm{a}}$ & $1.30 \pm 1.20^{\mathrm{a}}$ \\
\hline Ulcerated & $0.15 \pm 0.12^{\mathrm{b}}$ & $4.00 \pm 2.16^{\mathrm{a}}$ & $0.70 \pm 1.70^{\mathrm{b}}$ & $4.90 \pm 1.70^{\mathrm{b}}$ & $16.10 \pm 12.90^{\prime}$ \\
\hline
\end{tabular}


or epidermal tissues of the claw could generate the cytokines (Cooper et al., 2005) that drive the pathology associated with ulceration.

Ulcerative horn disease was associated with striking increases in IL-1 $\beta$ in the claw together with no change in IL-1 $\alpha$ expression in any segment other than the sole. Increased amounts of IL-1 $\beta$ in the context of little change in IL-1 $\alpha$ indicate that these 2 forms of IL- 1 may be regulated differently in the ulcerated claw. Indeed, similar events occur in psoriatic skin disease (Cooper et al., 1990). Most likely, influx of leukocytes during ulceration increased IL-1 $\beta$ transcription. Models in other species predict that elevated IL- $1 \alpha$ or IL- $1 \beta$ in ulcerated tissues should result in elevation of KGF, GMCSF, and KGFR expression (Werner et al., 1992; Chedid et al., 1994; Marchese et al., 1995; Finch et al., 1997). Although we observed an increase in KGFR transcription, there was a marked decrease in KGF transcription in the claw. Elevated KGFR expression could be expected to expand KGF-sensitive pools of basal and suprabasal cells and drive progenitor keratinocyte proliferation even though KGF transcription fell off in ulcerated tissues (Finch et al., 1997). Increased expression of IL-1TIIR and IL-1RA (albeit a very modest elevation relative to changes in IL-1 $\beta$ ) during ulceration could have blocked any IL- $1 \alpha$ or IL-1 $\beta$ stimulatory effect on growth factor expression. Alternatively, the findings may reflect the kinetics of KGF expression (Finch et al., 1997) in that KGF transcripts have been shown to increase early and decrease later after wounding. In contrast, KGFR transcripts decrease early and increase later in integument injury (Marchese et al., 1995). Another plausible explanation is that IL-1 $\beta$ transcription may have occurred in the absence of post-translational processing. Precursor forms of IL1 $\beta$ are biologically inactive and would not be expected to trigger KGF transcription. Formally establishing the existence of IL-1 $\beta$ processing in the claw may improve our understanding of the control of IL-1 $\beta$ activities in healthy and diseased claw tissues.

The broad-spectrum, potent anti-inflammatory mediator IL-10, but not the narrow-acting IL-1RTII, was elevated in chronic sole ulceration. Production of IL-10 in ulcerated claw tissues likely represents a powerful mechanism to limit the extent of inflammatory activity

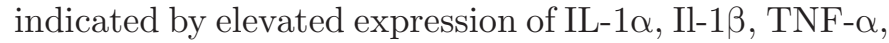
iNOS, and leukocytic infiltrates in tissues of ulcerated claws. Data from the ulcerated claws indicate that the epidermal-dermal tissues from every segment were positioned in the late inflammatory phase of cutaneous wound repair (Clark, 1996) and anti-inflammatory events had been initiated (Enk et al., 1995).

In summary, the data presented herein support the hypothesis that a variety of cytokines, growth factors, and receptors are differentially expressed in the epi- dermis and dermis of normal adult, fetal, and diseased bovine claws. Cytokines and growth factors expressed were similar to those thought to maintain tissue homeostasis in normal murine and human integuments. Inflammation effected mediator expression similarly across all segments of the claw and was consistent with a similar dissemination of the pathology. There was a small effect of claw age on cytokine expression because fetal tissues expressed large amounts of GMCSF relative to normal or diseased adult tissues. There was also an effect of claw segment on cytokine and growth factor expression that was related to differences in activity in the IL-1 axis.

\section{REFERENCES}

Amendt, C., A. Mann, P. Schirmacher, and M. Blessing. 2002. Resistance of keratinocytes to TGFbeta-mediated growth restriction and apoptosis induction accelerates re-epithelialization in skin wounds. J. Cell Sci. 115:2189-2198.

Banno, T., A. Gazel, and M. Blumenberg. 2004. Effects of tumor necrosis factor-alpha (TNF alpha) in epidermal keratinocytes revealed using global transcriptional profiling. J. Biol. Chem. 279:32633-32642.

Budras, K. D., C. Mulling, and A. Horowitz. 1996. Rate of keratinization of the wall segment of the hoof and its relation to width and structure of the zona alba (white line) with respect to claw disease in cattle. Am. J. Vet. Res. 57:444-455.

Chedid, M., J. S. Rubin, K. G. Csakey, and S. S. Aaronson. 1994 Regulation of keratinocyte growth factor expression by interleukin1. J. Biol. Chem. 269:10753-10757.

Clark, R. A. F. 1996. Wound repair: overview and general considerations. Pages 3-33 in The Molecular and Cellular Biology of Wound Repair. 2nd ed. R. A. F. Clark, ed. Plenum Press, New York, NY.

Clayton, E., D. P. Doupe, A. M. Klein, D. J. Winton, B. D. Simons, and P. H. Jones. 2007. A single type of progenitor cell maintains normal epidermis. Nature 446:185-189.

Collick, D. W., A. D. Weaver, and P. R. Greenough. 1997. Interdigital space and claw. Pages 101-122 in Lameness in Cattle. 3rd ed. P. R. Greenough and A. D. Weaver, ed. W. B. Saunders Co., Philadelphia, PA.

Cooper, K. D., C. Hammerberg, O. Baadsgaard, J. T. Elder, L. S. Chan, D. N. Saunder, J. J. Voorhees, and G. Fisher. 1990. IL-1 activity is reduced in psoriatic skin. Decreased IL-1 $\alpha$ and increased nonfunctional IL-1 $\beta$. J. Immunol. 144:4593-4603.

Cooper, L., C. Johnson, F. Burslem, and P. Martin. 2005. Wound healing and inflammation genes revealed by array analysis of 'macrophageless' PU.1 null mice. Genome Biol. 6:R5.

Enk, C. D., D. Sredni, A. Blauvelt, and S. I. Katz. 1995. Induction of IL-10 gene expression in human keratinocytes by UVB exposure in vivo and in vitro. J. Immunol. 154:4851-4856.

Finch, P. W., F. Murphy, I. Cardinale, and J. G. Krueger. 1997. Altered expression of keratinocyte growth factor and its receptor in psoriasis. Am. J. Pathol. 151:1619-1628.

Freedberg, I. M., M. Tomic-Canic, M. Komine, and M. Blumenberg. 2001. Keratins and the keratinocyte activation cycle. J. Invest. Dermatol. 116:633-640.

Groves, R. W., T. Rauschmayr, K. Nakamura, S. Sarkar, I. R. Williams, and T. S. Kupper. 1996. Inflammatory and hyperproliferative skin disease in mice that express elevated levels of the IL-1 receptor (type I) on epidermal keratinocytes. evidence that IL-1-inducible secondary cytokines produced by keratinocytes in vivo can cause skin disease. J. Clin. Invest. 98:336-344.

Hendry, K. A., C. H. Knight, H. Galbraith, and C. J. Wilde. 2003. Basement membrane integrity and keratinization in healthy and ulcerated bovine hoof tissue. J. Dairy Res. 70:19-27. 
Hinterhofer, C., J. C. Ferguson, V. Apprich, H. Haider, and C. Stanek. 2005. A finite element model of the bovine claw under static load for evaluation of different flooring conditions. N. Z. Vet. J. 53:165-170.

Ishida, Y., T. Kondo, A. Kimura, K. Matsushima, and N. Mukaida. 2006. Absence of IL-1 receptor antagonist impaired wound healing along with aberrant NF-kappaB activation and a reciprocal suppression of TGF-beta signal pathway. J. Immunol. 176:55985606.

Jiang, C. K., M. Tomic-Canic, D. J. Lucas, M. Simon, and M. Blumenberg. 1995. TGF beta promotes the basal phenotype of epidermal keratinocytes: Transcriptional induction of K5 and K14 keratin genes. Growth Factors 12:87-97.

Kessler-Becker, D., T. Krieg, and B. Eckes. 2004. Expression of proinflammatory markers by human dermal fibroblasts in a threedimensional culture model is mediated by an autocrine interleukin-1 loop. Biochem. J. 379:351-358.

Kondo, S., and K. Jimbow. 1998. Dose-dependent induction of IL12 but not IL-10 from human keratinocytes after exposure to ultraviolet light A. J. Cell. Physiol. 177:493-498.

Lischer, C. J., P. Ossent, M. Raber, and H. Geyer. 2002. Suspensory structures and supporting tissues of the third phalanx of cows and their relevance to the development of typical sole ulcers (Rusterholz ulcers). Vet. Rec. 151:694-698.

Livak, K. J., and T. D. Schmittgen. 2001. Analysis of relative gene expression data using real-time quantitative PCR and the 2(-delta delta $\mathrm{C}(\mathrm{T})$ ) method. Methods 25:402-408.

Maas-Szabowski, N., H. J. Stark, and N. E. Fusenig. 2000. Keratinocyte growth regulation in defined organotypic cultures through IL-1induced keratinocyte growth factor expression in resting fibroblasts. J. Invest. Dermatol. 114:1075-1084.

Marchese, C., M. Chedid, O. R. Dirsch, K. G. Csaky, F. Santanelli, C. Latini, W. J. LaRochelle, M. R. Torrisi, and S. A. Aaronson. 1995. Modulation of keratinocyte growth factor and its receptor in reepithelializing human skin. J. Exp. Med. 182:1369-1376.
Rauschmayr, T., R. W. Groves, and T. S. Kupper. 1997. Keratinocyte expression of the type 2 interleukin 1 receptor mediates local and specific inhibition of interleukin 1-mediated inflammation. Proc. Natl. Acad. Sci. USA 94:5814-5819.

Shearer, J., D. Anderson, W. Ayars, E. Belknap, S. Berry, C. Guard, K. Hoblet, E. Hovingh, G. Kirksey, A. Langill, A. Mills, D. Miskimins, J. Osterstock, R. Price, D. Prigel, A. Roussel, S. van Amstel, R. Wallace, J. Wasson, N. Cook, E. Garret, D. G. Hostetler, and L. Schugel. 2004. A record-keeping system for capture of lameness and foot-care information in cattle. Bovine Pract. 38:83-92.

Smola, H., G. Thiekotter, and N. E. Fusenig. 1993. Mutual induction of growth factor gene expression by epidermal-dermal cell interaction. J. Cell Biol. 122:417-429.

Stoll, S., G. Muller, M. Kurimoto, J. Saloga, T. Tanimoto, H. Yamauchi, H. Okamura, J. Knop, and A. H. Enk. 1997. Production of IL18 (IFN-gamma-inducing factor) messenger RNA and functional protein by murine keratinocytes. J. Immunol. 159:298-302.

Takei, T., H. Kito, W. Du, I. Mills, and B. E. Sumpio. 1998. Induction of interleukin (IL)-1 alpha and beta gene expression in human keratinocytes exposed to repetitive strain: Their role in straininduced keratinocyte proliferation and morphological change. J. Cell. Biochem. 69:95-103

Thoefner, M. B., O. Wattle, C. C. Pollitt, K. R. French, and S. S. Nielsen. 2005. Histopathology of oligofructose-induced acute laminitis in heifers. J. Dairy Sci. 88:2774-2782.

Werner, S., K. G. Peters, M. T. Longaker, F. Fuller-Pace, M. J. Banda, and L. T. Williams. 1992. Large induction of keratinocyte growth factor expression in the dermis during wound healing. Proc. Natl. Acad. Sci. USA 89:6896-6900.

Zavadil, J., M. Bitzer, D. Liang, Y. C. Yang, A. Massimi, S. Kneitz, E. Piek, and E. P. Bottinger. 2001. Genetic programs of epithelial cell plasticity directed by transforming growth factor-beta. Proc. Natl. Acad. Sci. USA 98:6686-6691. 